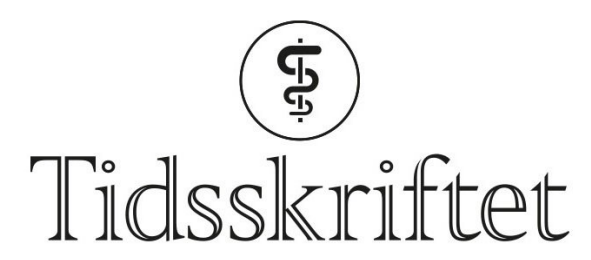

DEN NORSKE LEGEFORENING

\title{
Vitamin D-tilskudd forebygger ikke diabetes type 2
}

FRA ANDRE TIDSSKRIFTER

TORBJØRN ØYGARD SKODVIN

Tidsskriftet

Tilskudd forhindret ikke utvikling av diabetes hos pasienter med normalt nivå av vitamin D.

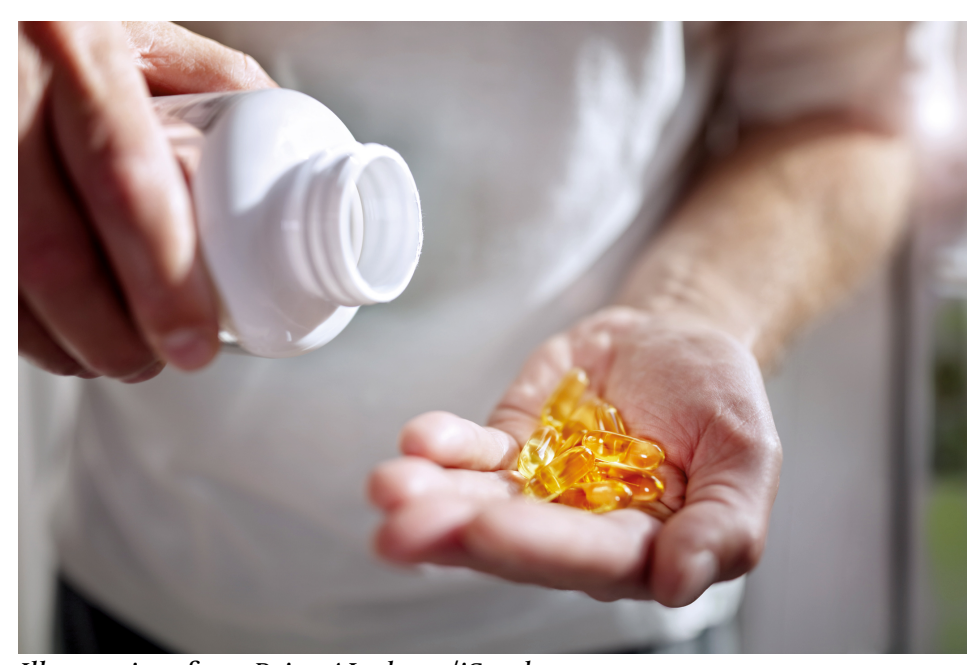

Illustrasjonsfoto: BrianAjackson/iStock

Vitamin D er viktig for skjelettet, men andre helseeffekter er mindre klare.

Observasjonsstudier har gitt mistanke om at lavt vitamin D-nivå øker risikoen for diabetes. For å teste dette randomiserte amerikanske forskere 2434 pasienter til å motta vitamin Dtilskudd eller placebo. Alle pasientene hadde prediabetes, det vil si forhøyet nivå av blodglukose eller $\mathrm{HbA}_{\mathrm{i}}$, men under grensene for diabetes. Både pasienter med og uten vitamin D-mangel ble inkludert (1).

Etter median oppfølgingstid på 2,5 år utviklet 293 pasienter i vitamin D-gruppen og 323 pasienter i placebogruppen diabetes. Dette ga en ikke-signifikant hasardratio på o,88 (95\% KI o,75-1,04, p = o,12).

Subgruppeanalyser ga usikre svar. Vitamin D-mangel defineres som < $50 \mathrm{nmol} / \mathrm{l}$. Blant de 103 deltagerne som ved studiestart hadde vitamin D-nivå < $30 \mathrm{nmol} / \mathrm{l}$, var hasardratio o,38 (95\% KI o,18-o,8o), mens deltagerne med nivå < $50 \mathrm{nmol} / \mathrm{l}$ hadde samme hasardratio som dem med $>50 \mathrm{nmol} / \mathrm{l}$ (henholdsvis 0,87 og o,89).

- Flertallet av studiedeltagerne hadde ikke reell vitamin D-mangel og derfor ikke noen nytte 
av ekstra tilskudd. Tilskudd av vitamin D vil uansett aldri få noen sentral plass i forebygging eller behandling av diabetes. Det sier Rolf Jorde, professor ved Universitetet i Troms $\emptyset$ Norges arktiske universitet og overlege ved Endokrinologisk seksjon, Universitetssykehuset Nord-Norge.

- Lavt nivå av vitamin $\mathrm{D}$, som sees ved en rekke sykdommer, fremstår mer som en markør enn som en årsak til sykdom. Det er likevel viktig å minne om at rakitt fortsatt er utbredt på verdensbasis, og betydningen av vitamin D-tilskudd i barneårene er fortsatt udiskutabel, sier Jorde.

LITTERATUR:

1. Pittas AG, Dawson-Hughes B, Sheehan P et al. Vitamin D supplementation and prevention of type 2 diabetes. N Engl J Med 2019;381: 520-30. [PubMed][CrossRef]

Publisert: 11. oktober 2019. Tidsskr Nor Legeforen. DOI: 10.4045/tidsskr.19.0511

(C) Tidsskrift for Den norske legeforening 2020. Lastet ned fra tidsskriftet.no 